DOI: $10.29303 /$ jrpb.v8i2.187

ISSN 2301-8119, e-ISSN 2443-1354

Tersedia online di http://jrpb.unram.ac.id

\title{
PENGEMBANGAN LISTRIK TENAGA BIOGAS SKALA RUMAH TANGGA UNTUK DAERAH TERPENCIL DI INDONESIA
}

\author{
Development of Family-Scale Biogas Electricity Generation for Isolated Areas in Indonesia
}

\author{
Agus Haryanto $^{1, *}$, Sugeng Triyono ${ }^{1}$, Mareli Telaumbanua ${ }^{1}$, Dwi Cahyani ${ }^{2}$ \\ ${ }^{1}$ Jurusan Teknik Pertanian, Fakultas Pertanian, Universitas Lampung \\ J1. Soemantri Brojonegoro No. 1, Bandar Lampung 35145, Indonesia \\ ${ }^{2}$ Program Studi Teknik Biosistem, Institut Teknologi Sumatera \\ Jl. Terusan Ryacudu, Way Huwi, Jati Agung, Lampung Selatan 35365, Indonesia
}

Email $\left.{ }^{*}\right)$ agus.haryanto@fp.unila.ac.id

Diterima: Juli 2020

Disetujui: September 2020

\begin{abstract}
The gap in electricity availability between urban and remote areas is one of the problems that must be resolved. Some remote areas provide independent electricity using diesel generators. One potential of renewable energy that can be exploited is the utilization of biogas from livestock waste as generator fuel. This paper aims to describe the potential of household-scale biogas power generators as one of the promising solutions for electrifying remote areas or islands in Indonesia. As an established technology, biogas technology offers various benefits as a renewable energy source. Biogas technology also offers side products in the form of highquality organic fertilizer. Household-scale biogas-fueled generators can be modified from small-sized gasoline-powered generators by adding biogas line in the carburetor. The results indicate that a household-scale biogas fueled generator is a suitable choice for the development of electricity in remote areas. The maximum benefit is obtained through an integrated system combining the activities of farming or gardening, animal husbandry, and the provision of biogas electricity. The high investment for digester construction and the price of biogas generators as well as the absence of incentives for biogas electricity are among the obstacles need to be overcome by involving stakeholders.
\end{abstract}

Keywords: biogas; isolated villages; electricity; renewable

\begin{abstract}
ABSTRAK
Kesenjangan ketersediaan listrik antara daerah perkotaan dan terpencil merupakan salah satu masalah yang harus diselesaikan. Sebagian daerah terpencil menyediakan listrik swadaya menggunakan generator diesel. Salah satu potensi energi terbarukan yang dapat dieksploitasi adalah pemanfaatan biogas dari limbah peternakan sebagai bahan bakar genset. Penelitian ini bertujuan untuk memaparkan potensi genset tenaga biogas skala rumah tangga sebagai salah satu solusi yang menjanjikan untuk melistriki daerah atau pulau terpencil di Indonesia. Sebagai teknologi yang sudah mapan, teknologi biogas menawarkan berbagai keuntungan sebagai sumber energi terbarukan. Teknologi biogas juga menawarkan produk samping berupa pupuk
\end{abstract}


organik yang berkualitas tinggi. Genset berbahan bakar biogas skala rumah tangga dapat dimodifikasi dari genset berbahan bakar bensin berukuran kecil yaitu dengan menambahkan jalur biogas pada karburator mesin. Hasil kajian menunjukkan bahwa genset skala rumah tangga berbahan bakar biogas merupakan salah satu alternatif pilihan yang baik untuk pengembangan listrik di wilayah terpencil. Manfaat maksimal diperoleh melalui sistem terintegrasi yang memadukan kegiatan kebun/pertanian, peternakan, dan penyediaan listrik biogas. Tingginya investasi pembuatan digester dan harga genset biogas serta tidak adanya insentif bagi listrik biogas merupakan kendala yang perlu diatasi dengan melibatkan para pemangku kepentingan.

Kata kunci: biogas; desa terpencil; listrik; terbarukan

\section{PENDAHULUAN}

Listrik telah menjadi kebutuhan pokok masyarakat dan nisbah antara jumlah rumah tangga berlistrik dengan jumlah rumah tangga total, disebut rasio elektrifikasi (RE), telah menjadi ukuran kesejahteraan. Pada tahun 2019, konsumsi energi listrik per kapita Indonesia baru mencapai $1.077 \mathrm{kWh}$ dengan RE 98,86\% (ESDM, 2019). Angka ini lebih tinggi daripada Philipina (94,9\%) dan Timor Leste $(85,6 \%)$ tetapi masih lebih rendah dari Singapura, Malaysia, Thailand, Vietnam, dan Brunei yang semuanya telah mencapai RE 100\% (The World Bank, 2020).

Pemerintah Indonesia telah mengidentifikasi potensi besar energi terbarukan yang dapat menjadi solusi untuk menjawab pertumbuhan permintaan listrik, sehingga mematok target rasio elektrifikasi mendekati $100 \%$ pada 2020 (Kirari et al., 2018). Hingga saat ini, masih terdapat 1,14\% (sekitar 3 juta) penduduk Indonesia atau 750 ribu rumah tangga yang tidak atau belum memiliki akses ke jaringan listrik. Umumnya masyarakat yang belum memperoleh listrik tinggal di daerah atau pulau-pulau terpencil. Daerah ini dicirikan dengan tidak adanya aktivitas industri, infrastruktur yang buruk, dan tidak terjangkau oleh jaringan listrik PLN. Masalah ini diperkuat oleh fakta bahwa Indonesia terdiri dari 16.000 lebih pulau. Jika tiap rumah tangga memerlukan daya listrik minimal 500 VA untuk memenuhi kebutuhan penerangan (sambungan listrik PLN paling rendah adalah $450 \mathrm{VA}$ ), dan pembangkit listrik beroperasi dengan efisiensi $80 \%$ dari kapasitasnya, maka akan diperlukan tambahan 337,5 MW daya baru hanya untuk mencukupi kebutuhan listrik di daerah terpencil.

Sebagian masyarakat di daerah terpencil telah mengusahakan sendiri kebutuhan daya listriknya menggunakan mesin generator (genset) kecil berbahan bakar minyak (BBM). Tetapi, BBM makin langka, mahal, dan sulit diperoleh di daerah terpencil. Jika harga minyak solar Rp 9.000 per liter dan efisiensi konversi 30\%, maka biaya pembangkitan listrik telah mencapai Rp 2.968 per $\mathrm{kWh}$ hanya untuk konsumsi bahan bakar. Harga ini jauh lebih mahal dibandingkan tarif listrik non subsidi bagi pelanggan pada Tegangan Rendah, yaitu Rp 1.467 per kWh (Kementerian ESDM, 2020).

Kebijakan Energi Nasional (KEN) mempunyai sasaran bauran energi yang optimal dengan kontribusi sumber daya energi baru dan terbarukan mencapai $23 \%$ pada tahun 2025 dan $31 \%$ pada tahun 2050 (Kementerian ESDM, 2016). Oleh karena itu, sangat penting mengembangkan sumber energi terbarukan di Indonesia yang potensinya sangat besar tetapi realisasinya masih sangat rendah. Pilihan terbaik melistriki masyarakat terpencil dan terisolir adalah pemanfaatan sumber daya energi yang tersedia secara lokal dengan menggunakan teknologi yang efisien, mapan, dan terjangkau secara ekonomi seperti: mikrohidro, biomasa, biogas, atau tenaga surya. Vaghmashi et al. (2014) menyatakan biogas memiliki potensi yang baik untuk menggantikan bahan bakar 
minyak. Pembangkit listrik tenaga biogas skala rumah tangga memiliki beberapa keunggulan yang patut dipertimbangkan sebagai alternatif.

Pemanfaatan biogas untuk listrik bukanlah teknologi baru. Tetapi, aplikasi pembangkitan listrik skala rumah tangga menggunakan bahan bakar biogas masih terbatas (Aisyah \& Herdiansyah, 2015). Sebagai contoh, hanya $7,5 \%$ dari 93 responden yang menggunakan biogas untuk listrik di Desa Mandiri Energi berbasis biogas, yaitu Desa Haurngombong, Kec. Pamulihan, Kabupaten Sumedang, Jawa Barat (Hermawati, 2012).

\section{Tujuan}

Tujuan artikel ini adalah melakukan ulasan mengenai pengembangan listrik biogas sebagai salah satu alternatif pemenuhan listrik di daerah terpencil. Artikel ini disusun menjadi empat bagian, yaitu latar belakang pentingnya listrik biogas, keunggulan listrik biogas, komponen sistem listrik biogas, sistem terintegrasi, prospek dan kendala listrik biogas, dan kesimpulan.

\section{HASIL DAN PEMBAHASAN}

\section{Keunggulan Listrik Biogas}

Biogas merupakan bahan bakar yang dihasilkan dari proses dekomposisi bahan organik yang terjadi dalam kondisi anaerobik. Dalam proses ini, bahan organik kompleks (protein, lemak, dan selulose atau pati) mengalami serangkaian dekomposisi oleh mikroorganisme yang dimulai dari hidrolisis menjadi monomer seperti asam amino, asam lemak rantai panjang, dan gula. Monomer ini akan terfermentasi membentuk asam lemak volatile (asam laktat, propionat, butirat) selama proses asidogenesis. Pada tahap asetogenesis, bakteri memakan asam lemak volatil ini untuk menghasilkan asam asetat, karbon dioksida $\left(\mathrm{CO}_{2}\right)$, dan hidrogen $\left(\mathrm{H}_{2}\right)$. Akhirnya, bakteri metanogenik menghasilkan metana $\left(\mathrm{CH}_{4}\right)$ dari asam asetat, $\mathrm{H}_{2}$, dan sebagian $\mathrm{CO}_{2}$ (Abbasi et al., 2012).

Komposisi utama biogas meliputi $\mathrm{CH}_{4}$ dan $\mathrm{CO}_{2}$, dengan sedikit gas inert, senyawa sulfur, dan uap air. Kandungan $\mathrm{CH}_{4}$ umumnya berkisar antara 55-70\% (Tabel 1). Komposisi biogas bevariasi bergantung pada substrat (bahan baku) yang digunakan. Umumnya, hasil biogas mencapai 100-200 $\mathrm{m}^{3}$ dari setiap ton bahan organik yang di degradasi (RISE-AT, 1998). Dalam proses ini juga dihasilkan kompos dan pupuk cair yang dapat digunakan untuk budidaya tanaman. Oleh karena itu, produksi dan penggunaan biogas memberikan manfaat sosial, ekonomi, dan lingkungan, baik bagi masyarakat secara keseluruhan maupun petani yang terlibat. Hal tersebut merupakan manfaat penting dari teknologi biogas (AlSeadi et al., 2008).

Tabel 1. Komposisi Tipikal Biogas (RISE-AT, 1998)

\begin{tabular}{lc}
\hline \multicolumn{1}{c}{ Komponen } & Kisaran \\
\hline Metana $\left(\mathrm{CH}_{4}\right)$ & $55-70 \% \mathrm{vol}$ \\
Karbon dioksida $\left(\mathrm{CO}_{2}\right)$ & $30-45 \% \mathrm{vol}$ \\
Hidrogen sulfida $\left(\mathrm{H}_{2} \mathrm{~S}\right)$ & $200-4000 \mathrm{ppm}$ vol \\
Nilai energi biogas & $20-25 \mathrm{MJ} / \mathrm{Nm}^{3}$ \\
\hline
\end{tabular}

Kandungan $\mathrm{CH}_{4}$ dalam biogas seperti dalam Tabel 1 mengisyaratkan bahwa biogas dapat digunakan sebagai bahan bakar untuk berbagai keperluan: masak, penerangan, dan pembangkitan listrik. Penggunaan biogas untuk menghasilkan listrik skala rumah tangga bisa menjadi salah satu solusi yang menjanjikan di daerah terpencil karena berbagai keunggulan yang ditawarkan.

\section{Sumber energi terbarukan}

Biogas adalah energi terbarukan karena dihasilkan dari biomasa. Substrat untuk proses biogas dapat dikembangkan secara lokal dan murah seperti kotoran sapi, limbah pertanian, atau tanaman energi. Biogas akan meningkatkan ketersediaan energi suatu daerah dan juga memberikan kontribusi penting dalam penyelamatan sumber daya alam dan perlindungan terhadap lingkungan. Pengembangan dan 
aplikasi sistem listrik biogas yang didasarkan pada potensi sumberdaya lokal akan meningkatkan pasokan energi dan ketahanan energi daerah sehingga mengurangi ketergantungan pada BBM (AlSeadi et al., 2008).

\section{Mengurangi emisi GRK}

Penggunaan bahan bakar fosil akan mengubah karbon yang telah tersimpan jutaan tahun di dalam bumi, dan melepasnya ke dalam atmosfer sebagai $\mathrm{CO}_{2}$. Peningkatan konsentrasi $\mathrm{CO}_{2}$ di atmosfer dapat menyebabkan pemanasan global karena $\mathrm{CO}_{2}$ merupakan salah satu gas rumah kaca (GRK). Pembakaran biogas juga menghasilkan $\mathrm{CO}_{2}$ ke atmosfer, tetapi secara keseluruhan netral karena dipakai oleh tanaman melalui proses fotosintesis. Daur ulang karbon dari biogas terjadi dalam waktu yang sangat singkat. Emisi $\mathrm{CH}_{4}$ dan $\mathrm{N}_{2} \mathrm{O}$ (dinitrogen oksida) yang terjadi pada timbunan dan aplikasi kotoran hewan juga dapat dikurangi melalui produksi biogas. Pontensi GRK $\mathrm{CH}_{4}$ adalah 21 kali lebih tinggi dari $\mathrm{CO}_{2}$ dan untuk $\mathrm{N}_{2} \mathrm{O} 296$ kali. Oleh karena itu, selain menggantikan BBM, listrik biogas juga mengurangi emisi GRK (Chynoweth et al., 2001) sehingga dapat menurunkan potensi pemanasan global (Mitianiec, 2012).

\section{Sumber pupuk organik}

Digester biogas tidak hanya menghasilkan energi. Lumpur yang keluar dari digester (dinamakan digestat) merupakan pupuk yang sangat baik karena kaya nitrogen, fosfor, potasium dan unsur hara mikro. Dibandingkan dengan kompos kotoran hewan yang tidak diolah, digestat lebih homogen, memiliki nutrisi lebih tersedia, $\mathrm{C} / \mathrm{N}$ rasio lebih baik, dan bau yang sudah jauh berkurang (Al-Seadi et al., 2008).

\section{Membuka lapangan pekerjaan}

Produksi biogas melalui proses anaerobik memerlukan tenaga kerja untuk produksi bahan baku, pengumpulan dan transportasinya, pembuatan perkakas teknis, konstruksi, pengoperasian dan perawatan digester biogas. Hal ini akan memberikan kontribusi terhadap pembukaan usaha baru yang memiliki potensi ekonomi signifikan, sehingga menciptakan lapangan kerja di perdesaan dan meningkatkan pendapatan (Al-Seadi et al., 2008).

\section{Modifikasi mudah}

Mesin genset berbahan bakar bensin dapat dikonversi ke biogas dengan mengubah karburator sehingga bisa beroperasi menggunakan bahan bakar gas. Konversi ini mudah dilakukan dan adaptor bahan bakar gas juga mudah diperoleh di pasaran.

\section{Beroperasi secara off-grid}

Pembangkit listrik rumah tangga beroperasi secara terdesentralisasi atau offgrid, sehingga tidak memerlukan pembuatan jaringan distribusi yang sangat mahal. Biaya pembuatan jaringan makin tinggi seiring dengan jaraknya sehingga sering menjadi kendala utama dalam pengembangan listrik di daerah yang sulit dijangkau oleh jaringan listrik pusat (Louie, 2018).

\section{Lebih ekonomis}

Terkait dengan aspek sosial-ekonomi masyarakat pedesaan, biogas yang dihasilkan dari sumber daya terbarukan merupakan pilihan yang tepat dan dapat memainkan peranan penting dalam memenuhi kebutuhan energi dan penyelesaian masalah lingkungan (Kabir et al., 2013). Berdasarkan analisis parameter secara menyeluruh, Chandra et al. (2012) menyimpulkan produksi biogas dari limbah pertanian lebih menguntungkan secara ekonomi dan lingkungan serta merupakan suatu cara menghasilkan energi dari biomassa secara berkelanjutan. Biogas lebih kompetitif dari sisi biaya dan efisien jika dibandingkan dengan bentuk energi biomassa lainnya seperti gas sintetik dan etanol (Chynoweth et al., 2001). Ditinjau dari harga bahan bakar, penggunaan biogas untuk operasional mesin, cenderung lebih 
hemat karena diperoleh secara gratis dibandingkan penggunaan dengan BBM dengan kisaran harga $\mathrm{Rp}$ 5.150-11.500 setiap liternya.

\section{Komponen Sistem}

Sistem pembangkit listrik biogas skala rumah tangga memerlukan komponen digester anaerobik, genset, dan beberapa komponen pendukung.

\section{Digester Anaerobik}

Digester adalah wadah anaerobik yang dipakai untuk mendekomposisi bahan organik dan menghasilkan biogas. Tabel 2 menyajikan perbandingan empat tipe digester yang dapat diaplikasikan di Indonesia. Dua tipe yang banyak diadopsi adalah digester tipe fixed-dome dan tipe plastik tubuler.

\section{Digester fixed-dome}

Digester ini terdiri dari digester (bagian bawah) berbentuk silinder dan bagian atas berbentuk kubah berfungsi sebagai gas-holder. Ketika produksi gas sudah dimulai, maka substrat yang menyerupai bubur (slurry) akan didorong ke kolam kompensasi. Tekanan gas akan terus meningkat seiring dengan peningkatan jumlah gas yang tersimpan dan setara dengan beda tinggi antara permukaan slurry di dalam digester dan permukaan slurry di dalam kolam kompensasi. Jika biogas dalam gas-holder tidak banyak, maka tekanan gas (terbaca pada manometer air) akan rendah. Sistem dilengkapi dengan bak pembuangan slurry berbentuk kotak yang berfungsi untuk menampung sementara lumpur dan untuk meningkatkan tekanan gas di dalam digester. Ukuran digester bervariasi dari 4 $\mathrm{m}^{3}$ hingga $12 \mathrm{~m}^{3}$ (Hariyanto, 2012). Disemininasi digester tipe fixed-dome di Indonesia difasilitasi oleh HIVOS melalui Program biogas rumah (BIRU). Gambar 1 dan 2 memperlihatkan desain dan aplikasi lapangan biogas tipe fixed dome.

Tabel 2. Perbandingan empat tipe digester (Warner et al., 1989)

\begin{tabular}{|c|c|c|c|}
\hline Faktor & Fixed dome & Floating drum & Plastik tubular \\
\hline $\begin{array}{l}\text { Penyimpanan } \\
\text { gas }\end{array}$ & $\begin{array}{l}\text { Penyimpanan gas internal } \\
\text { hingga } 20 \mathrm{~m}^{3} \text { (ukuran besar) }\end{array}$ & $\begin{array}{l}\text { Penyimpanan gas internal } \\
\text { ukuran drum (kecil) }\end{array}$ & $\begin{array}{l}\text { Penyimpanan gas eksternal } \\
\text { memakai kantung plastik }\end{array}$ \\
\hline Tekanan gas & Antara $60-120$ mbar & Hingga 20 mbar & Rendah, sekitar 2 mbar \\
\hline $\begin{array}{l}\text { Kemampuan } \\
\text { kontraktor }\end{array}$ & $\begin{array}{l}\text { Tinggi; tukang batu, tukang } \\
\text { pipa }\end{array}$ & $\begin{array}{l}\text { Tinggi; tukang batu, } \\
\text { tukang pipa, tukang las }\end{array}$ & Medium; tukang pipa \\
\hline $\begin{array}{l}\text { Ketersediaan } \\
\text { material }\end{array}$ & Ya & $\mathrm{Ya}$ & $\mathrm{Ya}$ \\
\hline $\begin{array}{l}\text { Ketahanan } \\
\text { (durability) }\end{array}$ & Sangat tinggi $>20$ tahun & $\begin{array}{l}\text { Tinggi; drum adalah titik } \\
\text { lemahnya }\end{array}$ & $\begin{array}{l}\text { Medium; tergantung pada } \\
\text { liner yang dipilih }\end{array}$ \\
\hline Pengadukan & Otomatis oleh tekanan biogas & Pengadukan manual & Tidak mungkin; tipe plug flow \\
\hline Ukuran & Volume digester $6-124 \mathrm{~m}^{3}$ & Hingga $20 \mathrm{~m}^{3}$ & Memungkinkan kombinasi \\
\hline Emisi metana & Tinggi & Medium & Rendah \\
\hline
\end{tabular}




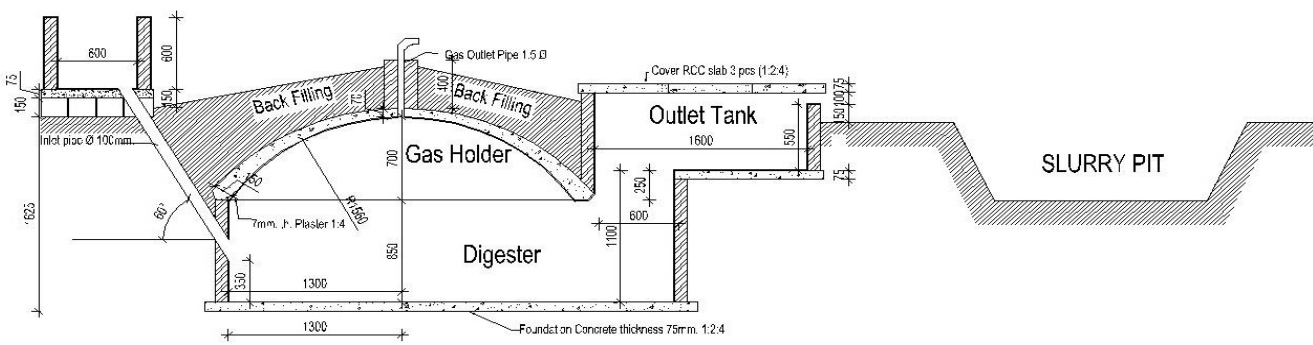

Gambar 1. Desain digester biogas fixed-dome BIRU yang dikembangkan di Indonesia (Menteri ESDM, 2014)

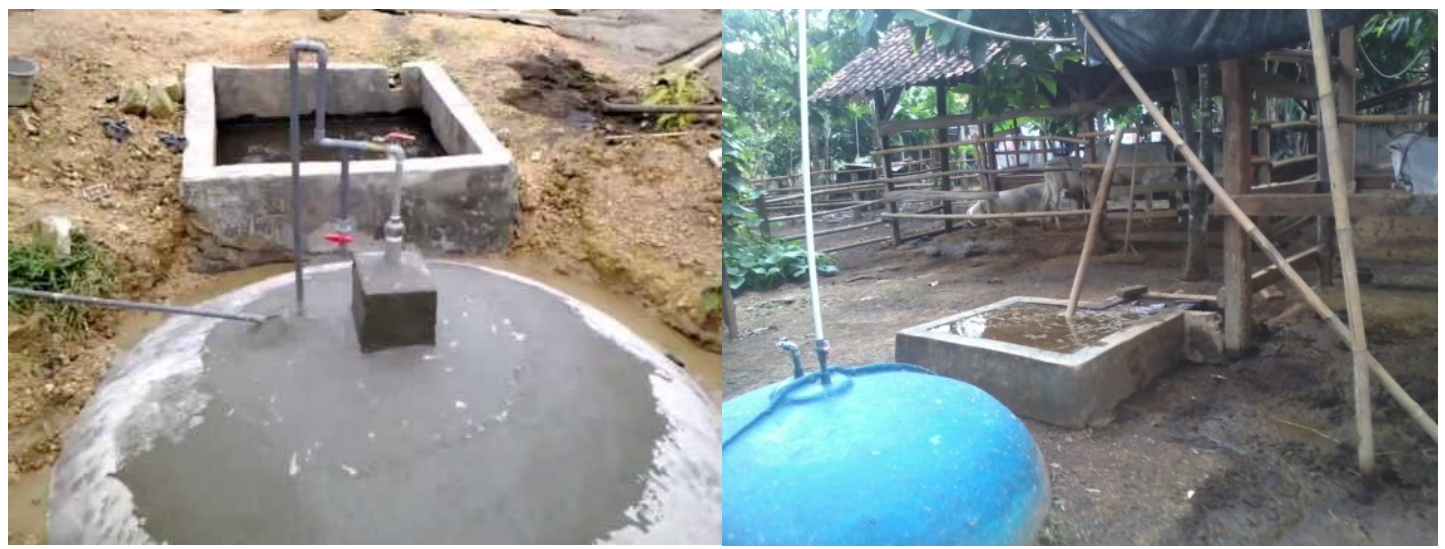

Gambar 2. Digester biogas tipe fixed-dome yang disebarluaskan melalui Program BIRU (kiri) dan tipe fixed-dome dari bahan fiber glass (Haryanto, 2012)

Digester tipe fixed dome sebenarnya sederhana karena tidak ada bagian yang bergerak. Digester dibangun di dalam tanah, sehingga terlindung dari kerusakan fisik dan hemat tempat. Fluktuasi suhu siang-malam tidak mempengaruhi proses mikro-biologis. Konstruksi digester fixed-dome memerlukan banyak tenaga kerja, sehingga menciptakan lapangan kerja lokal. Konstruksi digester fixed-dome memerlukan teknisi bangunan berpengalaman. Tukang tanpa pengalaman akan menghasilkan digester yang buruk (tidak kedap atau retak) (Warner et al., 1989).
Digester ini biasanya dibangun dari pasangan bata-semen, dan atau beton ferrocement. Kini, digester fixed- dome dari plastik atau fiber juga tersedia di pasaran. Parameter utama dalam pemilihan material meliputi: kesesuaian teknis (stabilitas, kekedapan gas- dan cairan), biaya, ketersediaan secara lokal dan ongkos transportasi, ketersediaan tenaga kerja terlatih lokal untuk mengerjakan beberapa material bangunan khusus (Warner et al., 1989). Digester ini dipasarkan dengan harga seperti diberikan pada Tabel 3.

Tabel 3. Kapasitas, kebutuhan substrat, dan harga digester BIRU di Indonesia (Hariyanto, 2012)

\begin{tabular}{cccccc}
\hline $\begin{array}{c}\text { Kapasitas } \\
\left(\mathbf{m}^{\mathbf{3}}\right)\end{array}$ & $\begin{array}{c}\text { Produksi Gas } \\
\left(\mathbf{m}^{\mathbf{3}} / \mathbf{h a r i}\right)\end{array}$ & $\begin{array}{c}\left.\text { Input Kotoran }^{\mathbf{a}}\right) \\
(\mathbf{k g} / \mathbf{h a r i})\end{array}$ & $\begin{array}{c}\text { Input Air } \\
(\mathbf{L} / \mathbf{h a r i})\end{array}$ & $\begin{array}{c}\text { Jumlah Sapi } \\
(\mathbf{e k o r})\end{array}$ & $\begin{array}{c}\text { Harga } \\
(\mathbf{R p})\end{array}$ \\
\hline 4 & $0,8-1,6$ & $20-40$ & $20-40$ & $3-4$ & 5.500 .000 \\
6 & $1,6-2,4$ & $40-60$ & $40-60$ & $5-6$ & 6.500 .000 \\
8 & $2,4-3,2$ & $60-80$ & $60-80$ & $7-8$ & 7.500 .000 \\
10 & $3,2-4,2$ & $80-100$ & $80-100$ & $9-10$ & 9.000 .000 \\
12 & $4,2-4,8$ & $100-120$ & $100-120$ & $11-12$ & 10.500 .000 \\
\hline
\end{tabular}

a) Rata-rata waktu tinggal (HRT) 50 hari

b) Tahun 2011 
Kekurangan digester ini adalah bahwa tekanan gas berfluktuasi sehingga aliran gas tidak konstan. Burner dan perkakas sederhana lainnya tidak dapat disusun secara optimal. Jika biogas digunakan untuk perkakas yang memerlukan tekanan konstan (misalnya, mesin genset), maka diperlukan regulator tekanan atau gas-holder apung (Warner et al., 1989).

\section{Digester Tipe Plastik Tubuler}

Digester tipe plastik tubuler (Gambar 3) awalnya dikembangkan di Amerika Latin (Bolivia, Peru, Ecuador, Colombia, dan Mexico). Digester ini menggunakan plastik PE (polyethylene) tubular dengan gas holder terpisah. Untuk keamanan, dapat dipakai dua lapis plastik dengan ketebalan masingmasing 300 mikron. Pada kedua ujungnya, plastik diikatkan melingkari pipa PVC 6" dan mengikatnya dengan tali karet. Salah satu ujung pipa PVC 6" digunakan sebagai saluran inlet dan ujung lainnya sebagai outlet. Di dalam digester akhirnya akan tercipta keseimbangan hidraulik antara jumlah substrat yang ditambahkan dengan digestat yang keluar. Hal ini karena plastik PE sangat fleksibel dan mudah rusak, maka digester perlu dilindungi. Digester dapat diletakkan dalam parit (lubang galian) atau bak memanjang. Naungan diperlukan untuk melindungi plastik dari radiasi UV matahari. Dari segi teknis dan biaya, digester plastik tubuler adalah yang paling sederhana dan paling murah (Aisyah \& Herdiansyah, 2015). Kelebihan dan kekurangan digester plastik diberikan pada Tabel 4. Digester ini direkomendasikan jika pembiayaan menjadi masalah yang substansial.

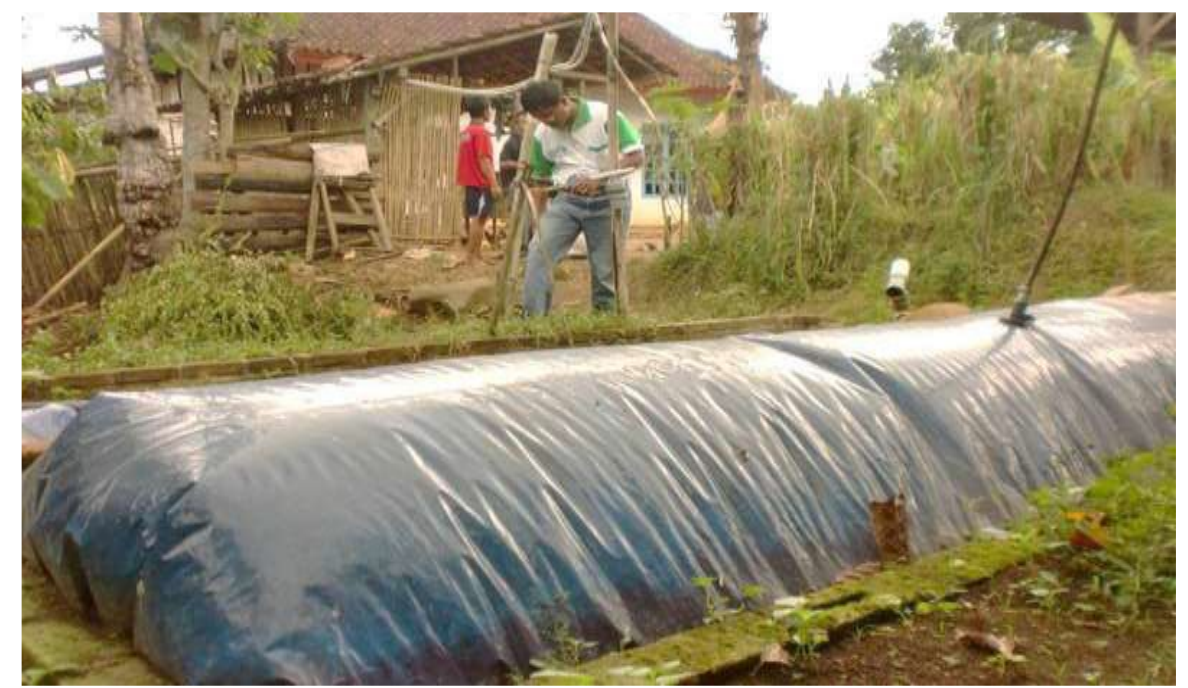

Gambar 3. Digester biogas tipe plastik tubuler (Foto: Agus Haryanto, 2011)

Tabel 4. Kelebihan dan kekurangan digester plastik tubuler (Warner et al., 1989)

\begin{tabular}{ll}
\hline \multicolumn{1}{c}{ Kelebihan } & \multicolumn{1}{c}{ Kekurangan } \\
\hline $\begin{array}{l}\text { Dapat dibuat secara standar dengan biaya rendah sebelum } \\
\text { instalasi }\end{array}$ & $\begin{array}{l}\text { Tekanan biogas yang rendah akan memerlukan } \\
\text { pembebanan atau pompa gas }\end{array}$ \\
$\begin{array}{l}\text { Sesuai untuk daerah dengan air permukaan yang rendah } \\
\text { karena dapat diinstal secara dangkal }\end{array}$ & $\begin{array}{l}\text { Scum tidak dapat diambil selama pengoperasian digester } \\
\text { Mudah transportasi }\end{array}$ \\
Konstruksi tidak rumit & Plastik memiliki umur pakai relatif singkat \\
Suhu digester tinggi di daerah beriklim hangat & Plastik biasanya tidak tersedia secara lokal \\
Pembersihan tidak rumit & Plastik rentan terhadap kerusakan mekanis \\
Digester bisa bekerja dengan substrat yang sulit & Potensi penciptaan tenaga kerja lokal sedikit \\
Mudah pengurasan dan perawatan & Kerusakan sulit diperbaiki \\
\hline
\end{tabular}


Digester Tipe Floating Tank

Digester biogas tipe floating tank diperkenalkan di India oleh Jashu Bhai J. Patel pada 1956 yang menamainya digester biogas Gobar (FAO, 1996). Digester ini terdiri dari digester yang terletak di bawah permukaan tanah dan sebuah gas-holder yang dapat dipindahkan. Digester berbentuk silinder dan gas-holder dari tangki atau drum yang mengapung baik secara langsung di atas bubur (slurry) atau mengapung pada selimut air (water jacket) dari gas-holder itu sendiri. Biogas dikumpulkan di dalam tangki gas yang akan naik atau turun, bergantung pada jumlah gas yang disimpan. Drum gas dipertahankan untuk tidak terjungkir oleh sebuah kerangka (guide frame). Jika biogas diproduksi, drum bergerak ke atas dan ketika biogas digunakan, drum bergerak ke bawah. Digester biogas Gobar ditinggalkan setelah masuknya digester model fixed-dome dari China, karena digester Gobar memerlukan investasi yang tinggi plus biaya perawatan akibat desain yang kurang sempurna.

Penulis menyederhanakan desain digester floating tank dengan digester berupa sumur plester sedalam $2 \mathrm{~m}$ dan pemanfaatan tangki air sebagai gas holder (Gambar 4). Drum dilengkapi tali dari kawat baja atau tambang plastik untuk mencegah agar drum tidak akan terjungkir.

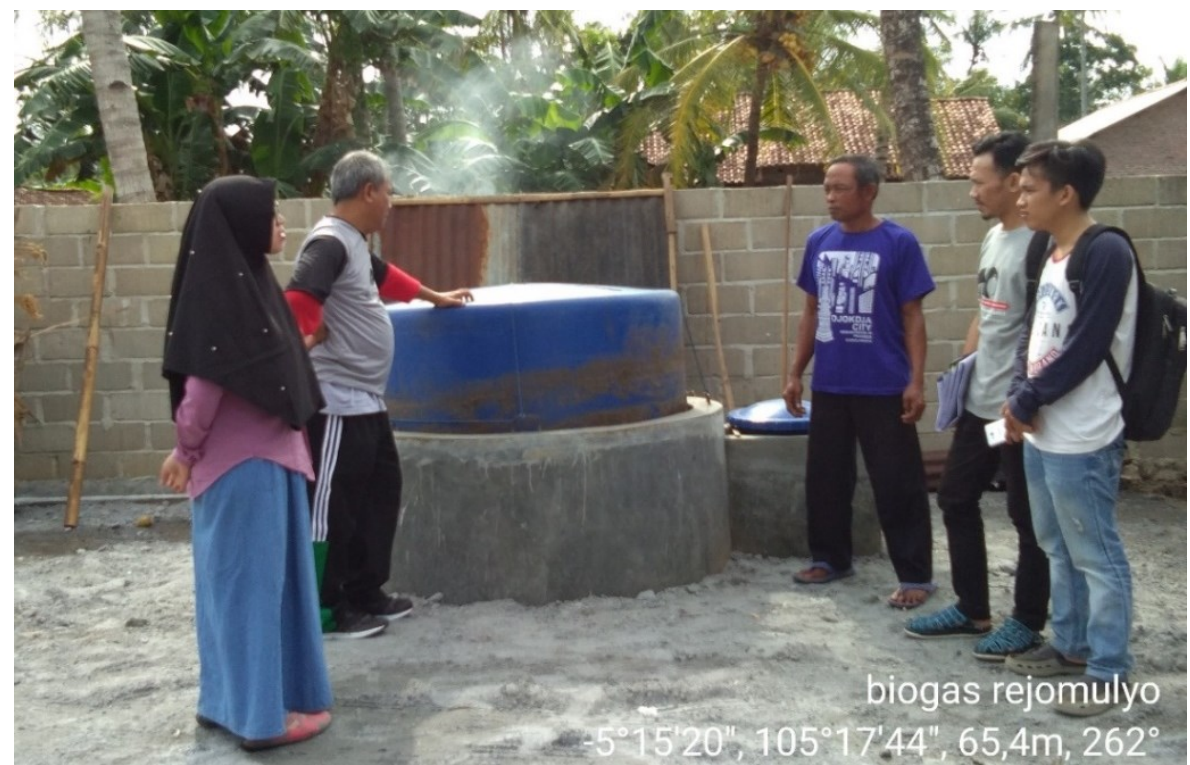

Gambar 4. Digester biogas tipe floating drum kerjasama Tim Penulis dengan Gapoktan Sido Rukun, Desa Rejomulyo, Lampung Selatan (Foto: Agus Haryanto, 2018)

\section{Genset Biogas}

Pembangkitan listrik tenaga biogas skala rumah tangga dapat dilakukan dengan mesin genset kecil. Biogas dapat dicampur dengan solar untuk mesin diesel atau dipakai sepenuhnya $(100 \%$ biogas) untuk mesin bensin. Daya yang dihasilkan dapat digunakan untuk menjalankan berbagai perkakas seperti refrigerator, kompresor, pembangkit daya listrik, dan pompa irigasi. Kini, generator kecil (kapasitas sekitar 1 $\mathrm{kW}$ ) dengan bahan bakar bensin makin banyak digunakan di wilayah pinggiran kota oleh kios kecil, rumah tangga, atau perkantoran untuk mengatasi listrik padam. Generator ini bisa dioperasikan sepenuhnya menggunakan biogas untuk mengatasi kelangkaan listrik di daerah terpencil. Tippayawong et al. (2010) melaporkan bahwa mesin dapat bekerja secara memuaskan dengan bahan bakar biogas tanpa modifikasi dan tidak terdapat masalah pada pengoperasian yang panjang. Genset berkapasitas 1,5 kW dilaporkan bekerja menggunakan $100 \%$ biogas. Meskipun konsumsi bahan bakar spesifik menggunakan biogas lebih tinggi, tetapi efisiensi puncak sebanding dengan mesin 
yang menggunakan bensin (Ehsan \& Naznin, 2005). Mesin bensin dapat dikonversi untuk beroperasi menggunakan biogas. Konversi ini dilakukan dengan merubah karburator sehingga dapat bekerja dengan bahan bakar gas. Jawurek et al. (1987) menyatakan bahwa konversi motor bensin ke motor gas merupakan pekerjaan sederhana. Para petani di Wilayah Sragi Lampung Selatan bahkan bisa mengerjakan sendiri konversi motor bensin untuk beroperasi menggunakan gas (LPG) untuk keperluan pompa irigasi (Haryanto et al., 2017a). Dari hasil kajiannya, Surata et al., (2014) juga melaporkan konversi sederhana motor bensin 4-tak silinder tunggal untuk menggerakkan generator listrik menggunakan bahan bakar biogas tanpa merubah rasio kompresi dari mesin orisinal. Mesin dilaporkan bekerja secara stabil dan dapat membangkitkan listrik dengan biogas $100 \%$ tanpa campuran. Perlengkapan atau kit konversi karburator ke bahan bakar gas kini bahkan sudah tersedia secara komersial.

\section{Komponen Pendukung}

Komponen pendukung yang penting adalah unit desulfurisasi untuk menurunkan kadar hidrogen sulfida $\left(\mathrm{H}_{2} \mathrm{~S}\right)$, unit water trap untuk mengambil uap air, dan unit $\mathrm{CO}_{2}$ remover untuk mengurangi kadar $\mathrm{CO}_{2}$.

\section{Desulfuriser}

Biogas mengandung hidrogen sulfida atau $\mathrm{H}_{2} \mathrm{~S}$ (Tabel 1). Meskipun sedikit, $\mathrm{H}_{2} \mathrm{~S}$ sangat membahayakan komponen dalam mesin seperti perapat (seal) dan katup. Senyawa ini sangat korosif terhadap bagianbagian logam di dalam mesin. Selain itu, pembakaran biogas yang mengandung $\mathrm{H}_{2} \mathrm{~S}$ akan menghasilkan sulfur dioksida $\left(\mathrm{SO}_{2}\right)$ yang beracun. Jika $\mathrm{SO}_{2}$ bereaksi dengan uap air, terbentuk asam sulfat $\left(\mathrm{H}_{2} \mathrm{SO}_{4}\right)$ yang menyebabkan korosi di dalam ruang bakar mesin dan pipa gas buang (knalpot). Senyawa $\mathrm{SO}_{2}$ juga larut di dalam oli mesin yang mengakibatkan oli menjadi asam, kehilangan daya lumas, dan mempersingkat masa penggantian oli (Cherosky, 2012; Muche \& Zimmermann, 1985). Genset dari jenis mesin bakar-dalam mensyaratkan kandungan $\mathrm{H}_{2} \mathrm{~S}$ dalam biogas kurang dari 100 ppm (McKinsey-Zicari, 2003).

$\mathrm{H}_{2} \mathrm{~S}$ dapat dihilangkan dari biogas dengan cara menyaring biogas tersebut menggunakan tanah alami atau bijih besi (ore) atau bahan besi oksida. Bahan ferrous ini dimasukkan ke dalam kontainer kedap udara yang terbuat dari baja atau plastik dengan tinggi tumpukan bahan ferrous 20 $30 \mathrm{~cm}$. Biogas dilewatkan dari bawah dan keluar di bagian atas kontainer. Biogas akan bebas dari $\mathrm{H}_{2} \mathrm{~S}$ melalui Persamaan reaksi 1 .

$$
\begin{aligned}
2 \mathrm{Fe}(\mathrm{OH})_{3}+3 \mathrm{H}_{2} \mathrm{~S} & \rightarrow \mathrm{Fe}_{2} \mathrm{~S}_{3}+6 \mathrm{H}_{2} \mathrm{O} \rightarrow \\
\mathrm{Fe}(\mathrm{OH})_{2}+\mathrm{H}_{2} \mathrm{~S} & \rightarrow \mathrm{FeS}+2 \mathrm{H}_{2} \mathrm{O} \ldots \ldots \ldots
\end{aligned}
$$

Proses ini akan berhenti setelah sebagian besar besi muncul sebagai sulfida (FeS dan $\mathrm{Fe}_{2} \mathrm{~S}_{3}$ ). Tetapi, sulfida besi ini dapat diregenerasi menggunakan oksigen atmosfer. Proses regenerasi ini dapat diulangi sampai 10 kali (Muche \& Zimmermann, 1985), sebelum akhirnya absorbent dibuang karena terlapisi dengan sulfur elementer dan pori-porinya menjadi tersumbat.

Kobayashi et al. (2012) mencatat metode desulfurisasi dapat dilakukan secara biologi seperti penggunaan bio-filter dan bio-scrubber. Desulfurisasi $\mathrm{H}_{2} \mathrm{~S}$ terjadi secara fisik melalui absorpsi oleh air atau secara biologi oleh mikroba. Proses absorpsi berlangsung melalui disosiasi (Horikawa et al., 2004) sesuai Persamaan reaksi 2, 3, dan 4.

$$
\begin{array}{ll}
\mathrm{H}_{2} \mathrm{~S}(\mathrm{~g})+\mathrm{H}_{2} \mathrm{O} & \leftrightarrow \mathrm{H}_{2} \mathrm{~S}(\mathrm{aq}) \\
\mathrm{H}_{2} \mathrm{~S}(\mathrm{aq}) & \leftrightarrow \\
\mathrm{HS}^{-} & \leftrightarrow \mathrm{H}^{+}+\mathrm{HS}^{-}
\end{array}
$$

Proses biologi dimulai dengan disosiasi $\mathrm{H}_{2} \mathrm{~S}$ yang menghasilkan $\mathrm{HS}^{-}$. Dalam kondisi oksigen terbatas, bakteri memfasilitasi reaksi redoks menghasilkan $\mathrm{S}^{0}$ (Abatzoglou, 2009) sesuai Persamaan reaksi 5.

$$
\mathrm{HS}^{-}+0,5 \mathrm{O}_{2} \rightarrow \mathrm{S}^{0}+\mathrm{OH}^{-}
$$


Su et al. (2013) melaporkan efisiensi pembuangan $\mathrm{H}_{2} \mathrm{~S}$ mencapai rata-rata $93 \%$ melalui desulfurisasi bio-filter. Penggunaan kompos kotoran sapi, McKinsey-Zicari (2003) menurunkan $\mathrm{H}_{2} \mathrm{~S}$ dari biogas dengan efisiensi mencapai $80 \%$. Haryanto et al. (2017b) melaporkan penggunaan bioscrubber dari kompos lokal dan memperoleh efisiensi 98\% untuk biogas yang dihasilkan dari limbah cair kelapa sawit.

\section{Water Trap}

Proses penguraian anaerobik terhadap bahan organik juga menghasilkan uap air. Oleh karena itu, biogas biasanya jenuh dengan uap air, yaitu memiliki kelembaban relatif $100 \%$. Air dihasilkan selama proses hidrolisis dan metanogenesis yang dapat dilihat dari Persamaan reaksi 6 dan 7 .

Hidrolisis:

$$
\left(\mathrm{C}_{6} \mathrm{H}_{12} \mathrm{O}_{6}\right)_{\mathrm{n}}+\mathrm{nH}_{2} \mathrm{O} \rightarrow \mathrm{nC}_{6} \mathrm{H}_{12} \mathrm{O}_{6}+\mathrm{nH}_{2} \mathrm{O} \ldots \text {. (6) }
$$

Metanogenesis:

$\mathrm{CO}_{2}+4 \mathrm{H}_{2} \rightarrow \mathrm{CH}_{4}+2 \mathrm{H}_{2} \mathrm{O}$

Adanya uap air di dalam biogas akan mengakibatkan biogas memiliki nilai energi yang rendah. Selain itu, uap air dapat menyebabkan korosi pada permukaan logam jika bereaksi dengan $\mathrm{H}_{2} \mathrm{~S}$. Oleh karena itu, biogas harus dikeringkan. Pengeringan biogas bisa terjadi selama pendinginan di sepanjang pipa ( $\mathrm{Scott} \&$ Tura, 2020). Tergantung pada panjang pipa yang menghubungkan antara digester dengan mesin, sebagian uap air mengalami kodensasi. Uap air yang telah mengalami kondensasi dapat dikumpulkan di dalam sebuah water trap berupa tabung ekspansi. Pipa yang mengalirkan biogas dilewatkan melalui tabung ekspansi sehingga uap air akan mengembun. Uap air yang mengembun akan tertampung di dalam tabung ekspansi dan dapat dibuang secara berkala.

\section{Sistem Terintegrasi}

Daerah pedesaan dan kegiatan agroindustri merupakan sumber biomasa terbesar. Di sini, jumlah limbah organik (limbah panen, kotoran hewan, efluen agroindustri, dan sebagainya) melimpah dan menjadi justifikasi bagi implementasi sistem konversi energi skala kecil yang terdesentralisasi untuk memenuhi kebutuhan energi lokal. Integrasi kegiatan peternakan, pertanian, dan penyediaan energi akan menghasilkan sistem ideal tanpa limbah. Menurut Gupta et al. (2012), sistem pertanian terintegrasi memiliki posisi spesial karena produk samping (by-product) dari satu sistem menjadi input bagi sistem lainnya. Gambar 5 menunjukkan sistem produksi dan pemanfaatan biogas yang terintegrasi dengan aktivitas pertanian dan peternakan. Modifikasi sistem diberikan oleh garis hijau dengan penjelasan pada budidaya tanaman akan menghasilkan limbah, seperti jerami, tebon jagung, atau biomassa lainnya yang dapat dimanfaatkan sebagai sumber pakan bagi ternak. Pakan juga dapat diperoleh langsung dari tanaman yang sengaja ditanam untuk pakan, misalnya rumput gajah. Selanjutnya, kotoran ternak merupakan substrat yang baik bagi digester anaerobik untuk menghasilkan biogas yang dapat digunakan untuk berbagai keperluan. Tambahan substrat organik juga dapat diperoleh dari limbah pertanian atau agroindustri. Digester biogas juga akan menghasilkan produk samping digestat yang dapat dimanfaatkan sebagai kompos yang berkualitas untuk proses budidaya tanaman. Dalam sistem terintegrasi, semua limbah ternak dapat diproses in-situ untuk menghasilkan biogas sebagai sumber energi alternatif. Dari sudut pandang lingkungan, sistem ini sangat baik dan dapat menjaga kelestarian sistem produksi.

Aktivitas peternakan warga masyarakat memiliki beberapa karakteristik yang membuatnya sesuai bagi implementasi sistem ini. Di satu sisi, terdapat limbah bahan organik dalam jumlah yang melimpah (terutama kotoran hewan dan sisa pakan). Di 
sisi lain, masyarakat memerlukan sumber energi untuk penerangan dan aktivitas lainnya. Wilayah dengan aktivitas peternakan sapi perah, merupakan lokasi yang sangat menguntungkan bagi integrasi ini karena susu sapi dapat didinginkan secara in-situ sehingga dapat memperpanjang umur simpan, mempertahankan cita rasa (organoleptik), dan mempertahankan nutrisi dan kualitasnya (Fiorelli \& Diaz, 2007).

Hasil penelitian Soelaeman \& Maswar (2014) mengenai integrasi ternak-tanamanbiogas menunjukkan bahwa seekor sapi menghasilkan kotoran dan urine sebanyak $11,25 \mathrm{~kg} / \mathrm{hari}$ dan produksi biogas dari digester berukuran $9 \mathrm{~m}^{3}$ mencapai $3 \mathrm{~m}^{3} /$ hari yang cukup untuk bahan bakar memasak dan penerangan sehari-hari. Produk samping dari digester biogas adalah lumpur $8 \mathrm{~kg} / \mathrm{hari}$ dan 127 liter/hari pupuk cair. Pemanfaatan produk samping (lumpur kering) sebagai pupuk pada tanaman jagung hibrida ditambah pupuk NPK sebanyak 50\% dari dosis rekomendasi memberikan hasil tertinggi sebesar 4,45 t/ha dengan keuntungan $\operatorname{Rp} 3.466 .000$ per ha dan rasio BC 1,5.

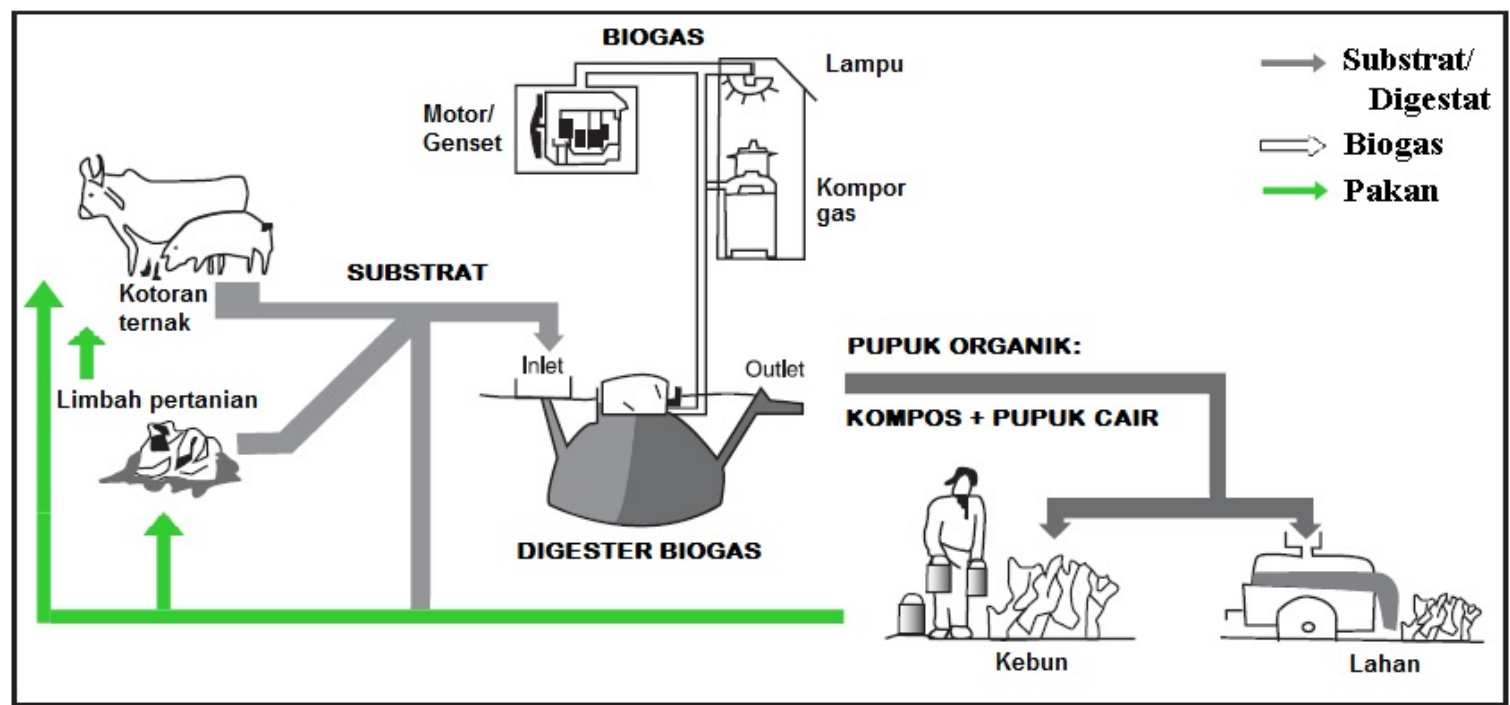

Gambar 5. Integrasi sistem tanaman-ternak-biogas (Warner et al., 1989, dimodifikasi).

\section{Prospek dan kendala}

Sesungguhnya teknologi biogas telah memberikan kontribusi yang penting bagi penyediaan energi di berbagai negara, baik negara maju maupun negara berkembang (Abraham et al., 2007). Beberapa negara seperti Jerman (Scheftelowitz and Thrän, 2016), China (Chen et al., 2014), India (Schmidt \& Dabur, 2014), Nepal (Barnhart (2014), Bangladesh (Khan et al., 2014), dan Vietnam (An et al., 1997) telah menikmati kesuksesan dari energi biogas. Pada akhir tahun 2010, China telah menginstal 41,2 juta digester biogas rumah tangga di daerah perdesaan dengan produksi biogas tahunan mencapai 15,5 miliar meter kubik (Feng et al., 2014). Kementerian Energi Baru dan Terbarukan India, telah berhasil menginstal 4,75 juta digester biogas di seluruh wilayah pada tahun 2014 (MOSPI, 2015). Barnhart (2014) melaporkan bahwa Nepal telah menginstal sekitar 250.000 unit digester biogas yang dapat menghemat pemakaian kayu bakar sebesar 239.386 ton per tahun dan 3,83 juta liter minyak tanah. Jumlah keseluruhan digester biogas yang telah diinstal di Vietnam mencapai sekitar 200.000 unit (Nguyen, 2011). Bangladesh telah menginstal lebih dari 40.000 unit digester biogas domestik menggunakan substrat kotoran sapi dan kotoran unggas (Khan et al., 2014). Melalui dukungan dari SNV, digester biogas domestik juga berkembang di Afrika. Pada tahun 2009, total digester biogas yang telah diinstal Afrika mencapai 53.617 (Ghimire, 2013).

Adopsi teknologi digester biogas rumah tangga di Indonesia berlangsung 
lambat dibandingkan negara-negara tersebut. Sejak tahun 2009, Indonesia telah menerima dukungan dari pemerintah negeri Belanda untuk mempromosikan digester biogas domestik melalui suatu program yang dinamakan Program Biogas Rumah Tangga yang lebih populer dengan nama BIRU (Biogas Rumah). Jumlah digester biogas yang ditargetkan untuk diinstal melalui program ini adalah 8.000 unit pada fase pertama dan 26.000 unit digester pada fase kedua (BIRU, 2015). Hingga Maret 2015, jumlah digester biogas yang telah diinstal mencapai 14.478 yang tersebar di sembilan provinsi (Vorley et al., 2015).

Indonesia memiliki potensi bahan organik yang melimpah yang berasal dari limbah pertanian, industri rumah tangga, agroindustri, peternakan, maupun tanaman yang sengaja ditanam untuk energi. Selain itu, Indonesia telah memiliki pengalaman panjang dalam pengembangan biogas rumah tangga yang dimulai sejak 1970-an. Oleh karena itu, prospek pengembangan listrik tenaga biogas skala rumah tangga terbuka lebar. Hal ini selaras dengan target pemerintah untuk menaikkan rasio elektrifikasi mendekati $100 \%$ pada tahun 2020 (Kirari et al., 2018) dan penurunan emisi GRK sebesar 29\%, maka peluang ini tidak boleh dilewatkan begitu saja.

Salah satu faktor yang secara tidak disadari menjadi kendala pengembangan teknologi biogas rumah tangga adalah penggunaan biogas itu sendiri untuk kepentingan memasak. Sejak tahun 2007, Indonesia telah melakukan program konversi minyak tanah ke LPG. Kebijakan ini dilakukan dengan pendistribusian kompor dan tabung LPG @ $3 \mathrm{~kg}$ kepada masyarakat hingga ke wilayah perdesaan. Pemanfaatan biogas rumah tangga terutama adalah untuk menggantikan LPG@3kg yang merupakan bahan bakar murah karena subsidi. Hal ini mengakibatkan keuntungan ekonomi biogas kurang menarik. Haryanto et al. (2017c) menyimpulkan bahwa keuntungan ekonomi biogas sebagai bahan bakar memasak hanya setara dengan 3 botol LPG@3kg per bulan atau sekitar Rp 60.000 per bulan. Jika diperhitungkan bahwa digester harus diisi setiap hari, maka keuntungan sebesar ini kurang menarik. Oleh karena itu, diversifikasi pemanfaatan biogas sebagai bahan bakar pembangkit listrik rumah tangga akan lebih menarik masyarakat untuk berinvestasi. Selain itu, bahan bakar biomasa masih tersedia melimpah di daerah terpencil.

Faktor lain yang perlu diperhitungkan bagi keberhasilan pengembangan listrik biogas rumah tangga, antara lain:

a. Lemahnya koordinasi di antara pihakpihak yang memiliki program biogas.

b. Tingginya investasi pembuatan digester dan harga genset biogas.

c. Belum adanya insentif yang diberikan oleh pemerintah bagi masyarakat yang terlibat dalam pengembangan dan pemanfaatan biogas.

Sulitnya pendanaan bagi masyarakat perlu diatasi dengan melibatkan berbagai pihak, seperti swasta melalui program CSR, lembaga pemerintah dan perguruan tinggi melalui program pengabdian masyarakat.

\section{KESIMPULAN}

Genset tenaga biogas skala rumah tangga merupakan teknologi yang menjanjikan untuk menyuplai listrik bagi daerah terpencil dan terisolir di Indonesia. Komponen sistem pembangkit listrik tenaga biogas skala kecil terdiri dari digester anaerobik untuk menghasilkan biogas, mesin genset yang telah dimodifikasi untuk dapat menggunakan bahan bakar biogas, unit desulfuriser untuk menurunkan kadar $\mathrm{H}_{2} \mathrm{~S}$ yang bersifat korosif bagi genset dan unit water trap untuk menurunkan kadar air biogas. Untuk memberikan nilai tambah yang maksimal, perlu diterapkan sistem terintegrasi yang memadukan kegiatan kebun/pertanian, peternakan, dan penyediaan listrik biogas. Tingginya investasi pembuatan digester dan harga genset biogas serta tidak adanya insentif bagi listrik biogas merupakan kendala yang perlu diatasi dengan melibatkan para pemangku kepentingan. 


\section{DAFTAR REFERENSI}

Abatzoglou, N. (2009). A review of biogas purification processes. Biofuels, Bioproduct, Biorefinery, 3: 42-71.

Abbasi, T., Tauseef, S.M., Abbasi, S.A. (2012). Biogas Energy. Springer, New York: 1-10.

Abraham, E.R., Ramachandran, S., Ramalingam, V. (2007). Biogas: Can it be an important source of energy? Environmental Science and Pollution Research, 14(1): 67-71.

Aisyah, I. U., Herdiansyah, S. (2015). Strategi pemberdayaan masyarakat dalam pelaksanaan program Desa Mandiri Energi. Share: Social Work Journal, 9(3): 130-141.

Al-Seadi, T., Rutz, D., Prassl, H., Köttner, M., Finsterwalder, T., Volk, S., Janssen, R. (2008). Biogas Handbook. University of Southern Denmark, Niels Bohrs Vej 9-10, DK-6700 Esbjerg, Denmark.

An, B.X., Preston, T.R., Dolberg, F. (1997). The introduction of low-cost polyethylene tube biodigesters on small scale farms in vietnam. Livestock Research for Rural Development, 11(1). http://www.lrrd.org//rrd9/2/an92.htm (Accessed July 10, 2015).

Barnhart, S. (2014). From household decisions to global networks: biogas and the allure of carbon trading in Nepal. The Professional Geographer, 66(3): 345-353.

BIRU (Biogas Rumah). (2015). Annual Report Indonesia Domestic Biogas Programme January - December 2014.
Chandra, R., Takeuchi, H., Hasegawa, T. (2012). Methane production from lignocellulosic agricultural crop wastes: a review in context to second generation of biofuel production. Renewable Sustainable Energy Review, 16: 1462-1476.

Chen, Y., Hua, W., Feng, Y., \& Sweeney, S. (2014). Status and prospects of rural biogas development in China. Renewable and Sustainable Energy Reviews, 39: 679-685.

Cherosky, P.B. (2012). Anaerobic digestion of yard waste and biogas purification by removal of hydrogen sulfide. Master Thesis. Graduate Program in Food, Agricultural and Biological Engineering, Ohio State University.

Chynoweth, D.P., Owens, J.M., Legrand, R. (2001). Renewable methane from anaerobic digestion of biomass. Renewable Energy, 22(3): 1-8.

Ehsan, M., Naznin, N. (2005). Performance of a biogas run petrol engine for small scale power generation. Journal of Energy \& Environment, 4: 1-9.

ESDM (Energi dan Sumber Daya Mineral). (2019). Bahan Media Gathering Direk-torat Pembinaan Program Ketenagalistrikan.

www.gatrik.esdm.go.id (Diakses 1 Juni 2020).

FAO (Food and Agriculture Organization). (1996). Biogas Technology: A Training Manual for Extension. Consolidated Management Services Nepal (P) Ltd., Kathmandu, Nepal.

Feng, Y., Guo, Y., Yang, Y., Qin, X., \& Song, Z. (2014). Household biogas development in rural China: On policy support and other macro sustainable conditions. Renewable and 
Sustainable Energy Reviews, 16: 679685.

Fiorelli, F.A.S. and Diaz, G.O. (2007). Anaerobic digestion as centre of dairy livestock and agriculture integration: basis for medium-scale CDM projects development. Engenharia Térmica (Thermal Engineering), 6(02): 8-13.

Ghimire, P.C. (2013). SNV supported domestic biogas programmes in Asia and Africa. Renewable Energy, 49: 90-94.

Gupta, V., Rai, P.K., Risam, K.S. (2012). Integrated crop-livestock farming systems: A strategy for resource conservation and environmental sustainability. Indian Research Journal of Extension Education, II (Special Issue): 49-54.

Hariyanto. (2012). Model Pengembang-an Energi Alternatif Biogas di KPSP Setia Kawan. Workshop Koordinasi Program Biogas Rumah (BIRU), Lampung, 23 Oktober 2012.

Haryanto, A., Suharyadi, Lanya, B. (2017a). Pemanfaatan air tanah dangkal untuk irigasi padi menggunakan pompa berbahan bakar LPG. Jurnal Keteknikan Pertanian, 5(3): 219-226.

Haryanto, A., Marotin, F., Triyono, S., Hasanudin, U. (2017b). Developing a family-size biogas-fueled electricity generating system. IJRED, 6(2): 111118.

Haryanto, A., Cahyani, D., Triyono, S., Murdapa, F., Haryono, D. (2017c). Economic benefit and greenhouse gas emission reduction potential of a family-scale cowdung anaerobic biogas digester. IJRED, 6(1): 29-36.

Hermawati, N. (2012). Analisis Dampak Ekonomi, Sosial dan Lingkungan dari
Pemanfaatan Limbah Ternak Sapi Perah: Studi Kasus di Desa Haurngombong, Kecamatan Pamulihan, Kabupaten Sumedang, Jawa Barat. Skripsi. Departemen Ekonomi Sumberdaya dan Lingkungan, Fakultas Ekonomi dan Manajemen, Institut Pertanian Bogor.

Horikawa, M.S., Rossi, F., Gimenes, M.L., Costa, C.M.M., da Silva, M.G.C. (2004). Chemical absorption of $\mathrm{H}_{2} \mathrm{~S}$ for biogas purification. Brazilian Journal of Chemical Engineering, 21(03): 415-422.

Jawurek, H.H., Lane, N.W., Rallis, C.J. (1987). Biogas/petrol dual fuelling of SI engine for rural third world use. Biomass, 13(2): 87-103.

Kabir, H., Yegbemey, R.N., Bauer, S. (2013). Factors determinant of biogas adoption in Bangladesh. Renewable Sustainable Energy Review, 28: 881889.

Kementerian ESDM (Energi dan Sumber Daya Mineral). (2016). Rencana Usaha Penyediaan Tenaga Listrik PT. Perusahaan Listrik Negara (Persero) Tahun 2016 s.d. 2025. Jakarta.

Kementerian ESDM. (2020). Tarif Tenaga Listrik Periode Juli-September 2020 Tidak Naik. Siaran Pers Nomor: 194.Pers/04/ SJI/2020, (3 Juni 2020).

Khan, U.K., Mainali, B., Martin, A., \& Silveira, S. (2014). Techno-economic analysis of small scale biogas based polygeneration systems: Bangladesh case study. Sustainable Energy Technologies and Assessments, 7: 6878.

Kirari J.K., Adel, M., Andria, V., Lakaseru, B.O. (2018) Supporting Indonesia's Renewable Energy Development in 
Remote and Rural Areas through Innovative Funding. Jakarta.

Kobayashi, T., Li, Y-Y., Kubota, K., Harada, H., Maeda, T., Yu, H-Q. (2012). Characterization of sulfideoxidizing microbial mats developed inside a full-scale anaerobic digester employing biological desulfurization. Applied Microbiology and Biotechnology, 93: 847-857.

Louie, H. (2018). Off-Grid Electrical Systems in Developing Countries. Springer International Publishing AG, Switzerland: 53-82.

McKinsey-Zicari, S. (2003). Removal of hydrogen sulphyde using cow manure compost. Department of Biological and Environmental Engineering, Cornel University (Master Thesis).

Menteri ESDM (Energi dan Sumber Daya Mineral). (2014), Peraturan Menteri Energi dan Sumber Daya Mineral Republik Indonesia No. 03/2014 tentang Petunjuk Teknis Penggunaan Dana Alokasi Khusus Bidang Energi Perdesaan Tahun Anggaran 2014.

Mitianiec, W. (2012). Factors determining ignition and efficient combustion in modern engines operating on gaseous fuels. Internal Combustion Engines (Lejda, K. and Woś, P., editors). InTech, Janeza Trdine 9, Rijeka, Croatia: 3-34.

MOSPI (Ministry of Statistics and Programme Implementation). (2015). Energy Statistics 2015. Central Statistics Office, Government of India. New Delhi: 12-20.

Muche, H. and Zimmermann, H. (1985). The Purification of Biogas. Gesellschaft für Technische Zusammenarbeit (GTZ).
Nguyen, V. C. N. (2011). Small-scale anaerobic digesters in Vietnam Development and challenges. Journal of Vietnamese Environment, 1(1) : 1218.

RISE-AT (Regional Information Service Centre for South East Asia on Appropriate Technology). (1998). Review of current status of anaerobic digestion technology for treatment of municipal solid waste. (Accessed from

http://www.ist.cmu.ac.th/riseat/docu ments/adreview.pdf).

Scheftelowitz, M., Thrän, D., (2016). Unlocking the energy potential of manure - An assessment of the biogas production potential at the farm level in Germany. Agriculture, 6: 1-20.

Schmidt, T. S., Dabur, S. (2014). Explaining the diffusion of biogas in India: a new functional approach considering national borders and technology transfer. Environmental Economics and Policy Studies, 16: 171-199.

Scott, S., Tura, F. (2020). Six reasons to dry biogas to a low dewpoint before combustion in a CHP engine. Diakses dari:

https://www.parker.com/literature/Un ited\%20Kingdom/PAR6841_Whitepa per_v3.pdf (29 Juli 2020).

Soelaeman, Y., Maswar. (2014). Integration of crop-livestock-biogas and the effect of dried sludge manure on the growth and yield of maize on ultisol soil. Agrivita, 36(2): 160-168.

Su, J-J., Chang, Y-C., Chen, Y-J., Chang, KC., Lee, S-Y. (2013) Hydrogen sulfide removal from livestock biogas by a farm-scale bio-filter desulfurization system. Water Science and Technology, 67(6): 1288-1293. 
Surata, I.W., Nindhia, T.G.T., Atmika, I.K.A., Negara, D.N.K.P., Putra, I.W.E.P. (2014). Simple conversion method from gasoline to biogas fueled small engine to powered electric generator. Energy Procedia, 52: 626632.

The World Bank. (2020). World Development Indicators. https://databank.worldbank.org/report s.aspx? source $=2 \&$ series $=$ EG.ELC.A CCS.ZS\&country $=$ VNM\# $\quad(23$ Juli 2020).

Tippayawong, N., Promwungkwa, A., Rerkkriangkrai, P. (2010). Durability of a small agricultural engine on biogas/diesel dual fuel operation. Iranian Journal of Science and Technology, Transactions B, 34(B2): 167-177.
Vaghmashi, J.D., Shah, D.R., Gosai, D.C. (2014). An experimental study of petrol engine using compressed biogas as a fuel. International Journal for Scientific Research \& Development, 2(04): 121-124.

Vorley, B., Porras, I., Amrein, A. (2015). The Indonesia Domestic Biogas Programme: Can Carbon Financing Promote Sustainable Agriculture? International Institute for Environment and Development and Hivos, London: 10.

Warner, U., Stöhr, U., Hees, N. (1989). Biogas plants in animal husbandry. GTZ (Gesellschaft für Technische Zusammen-arbeit), Eschborn I, Federal Republic of Germany: 153 hal. 